\title{
Leiomyoadenomatoid tumor of uterus: two case reports with literature review
}

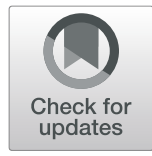

Flora Ávila Adorno ${ }^{1,2^{*}}$, Karina Munhoz de Paula Alves Coelho ${ }^{2,3}$, Giuliano Stefanello Bublitz ${ }^{2}$, Jaqueline Stall ${ }^{2,3}$ and Paulo Henrique Condeixa de França ${ }^{3}$

\begin{abstract}
Background: Adenomatoid tumors (AT) are benign neoplasms of mesothelial origin that occur more frequently in the genital tracts. In uterus, AT are usually located in the subserosa of the cornual myometrium. Microscopically, it is characterized by interanastomosing pseudoglands or pseudovascular spaces and striking smooth-muscle hypertrophy is often present. In some cases, the prominence of smooth muscle component simulates a leiomyoma and the lesion is denoted as a leiomyoadenomatoid tumor. The microscopic appearance of the adenomatoid component (AC) may mimic a malignant tumor due to irregular pseudoinfiltration with tubular formations. Just 16 cases with this morphological presentation were found in the literature review.

Case presentations: The first case, a 38-year-old female, showed lower abdominal pain, menorrhagia, postcoital bleeding and previous history of uterin leiomyoma. The second case, a 26-year-old female, had clinical complaint of metrorrhagia and received diagnostic hypothesis of leiomyoma after ultrasound image. Both underwent myomectomy. Microscopically, the uterine masses showed intersecting smooth muscle bundles and gland like areas lined by cuboidal epithelioid cells that stained positive for WT1, D2-40 and calretinin in immunohistochemical analysis.
\end{abstract}

Conclusions: The cases were diagnosed as leiomyoadenomatoid tumor of the uterus. This is a benign and rare entity that may mimic malignant tumors due to the pseudo infiltrative appereance of the adenomatoid component, possibly leading to misdiagnosis.

Keywords: Adenomatoid tumor, Uterine neoplasms, Smooth muscle

\section{Background}

Adenomatoid tumors (AT) are benign neoplasms of mesothelial origin that occur more frequently in the genital tracts of both men and women. In uterus, AT are usually located in the subserosa of the cornual myometrium. Lesions are typically solitary, but multicentric cases have been reported (Amre et al. 2005; Mathew and Goel 2010; Kurman et al. 2014). Microscopically, AT show interanastomosing pseudoglands or pseudovascular

\footnotetext{
* Correspondence: decipe@cedap.com.br

'Pathology Residency Program, São José Municipal Hospital, Joinville, Santa

Catarina, Brazil

${ }^{2}$ Centro de Diagnósticos Anátomo-Patológicos (CEDAP), Joinville, Santa

Catarina, Brazil

Full list of author information is available at the end of the article
}

spaces, and a smooth-muscle component is often present (Kurman et al. 2014).

In some cases, the prominence of smooth muscle component simulates a leiomyoma and the lesion is denoted as a "leiomyoadenomatoid tumor". In this morphological pattern, the microscopic appearance of the adenomatoid component (AC) may mimic a malignant tumor due to irregular pseudoinfiltration with tubular formations (Amre et al. 2005; Bedir et al. 2014; Kurman et al. 2014). There were found only 16 cases of this morphological presentation in our literature review.

In this paper we report two cases of leiomyoadenomatoid tumors of the uterus with emphasis on the morphologic and immunohistochemical findings, besides

(c) The Author(s). 2021 Open Access This article is licensed under a Creative Commons Attribution 4.0 International License, which permits use, sharing, adaptation, distribution and reproduction in any medium or format, as long as you give appropriate credit to the original author(s) and the source, provide a link to the Creative Commons licence, and indicate if changes were made. The images or other third party material in this article are included in the article's Creative Commons licence, unless indicated otherwise in a credit line to the material. If material is not included in the article's Creative Commons licence and your intended use is not permitted by statutory regulation or exceeds the permitted use, you will need to obtain permission directly from the copyright holder. To view a copy of this licence, visit http://creativecommons.org/licenses/by/4.0/. 
discussing the diagnostic difficulties along with a brief review of the literature.

\section{Case presentation}

The first case, a 38-year-old female attended the gynecology clinic with lower abdominal pain, menorrhagia, postcoital bleeding and ultrasound images of the uterus suggestive of leiomyoma. There was no abnormality in cervical cytology and no improvement of postcoital bleeding after cervical cauterization. The patient underwent a myomectomy. The other case was a 26year-old female with metrorrhagia. The patient received the diagnostic hypothesis of leiomyoma retrieved from ultrasound image and was also subjected to myomectomy.

A $3.8 \times 2.9 \times 2.5 \mathrm{~cm}$ mass was obtained from the first case. In the second, the mass measured $3.3 \times 3.1 \times 2.9$ $\mathrm{cm}$. Gross examination of the masses revealed a nodular aspect and ragged surface. The cut surface revealed a whorled appearance.

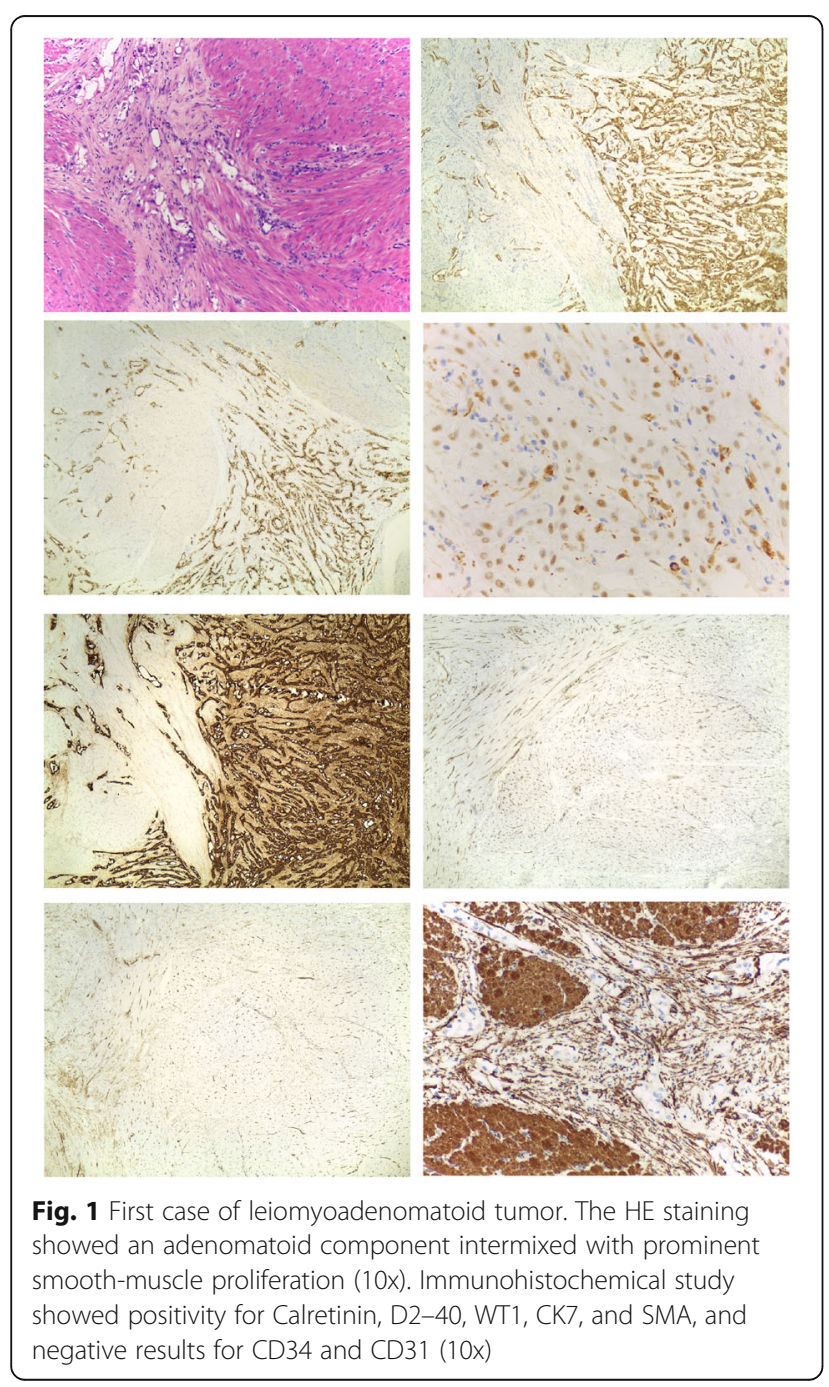

Microscopically, the uterine mass showed intersected hypertrophic smooth-muscle bundles. Organized multifocal pseudovascular and pseudoglandular areas arranged in cystic and tubular spaces were seen. These spaces were lined by cuboidal epithelioid cells with scanty, pale, and eosinophilic vacuolated cytoplasm with occasional signet ring-like cells. No abnormal mitotic activity or cytological atypia were seen.

Immunohistochemical investigations were performed in both cases. The first case stained positive for cytokeratin 7 (CK7) in AC and negative for CK20. CDX-2, PAX8 and vascular markers CD31, CD34 and ERG were negative. The second case presented positivity for cytokeratins EA1-AE3 and low proliferative Ki-67 index.

Both tumors showed expression of WT-1, D2-40 and calretinin, supporting the hypothesis of mesothelial nature of the lining epithelial cells in AC. The SMA expression was confirmed in smooth muscle component in both cases. Therefore, the cases were diagnosed as AT of the uterus with a prominent muscular component -

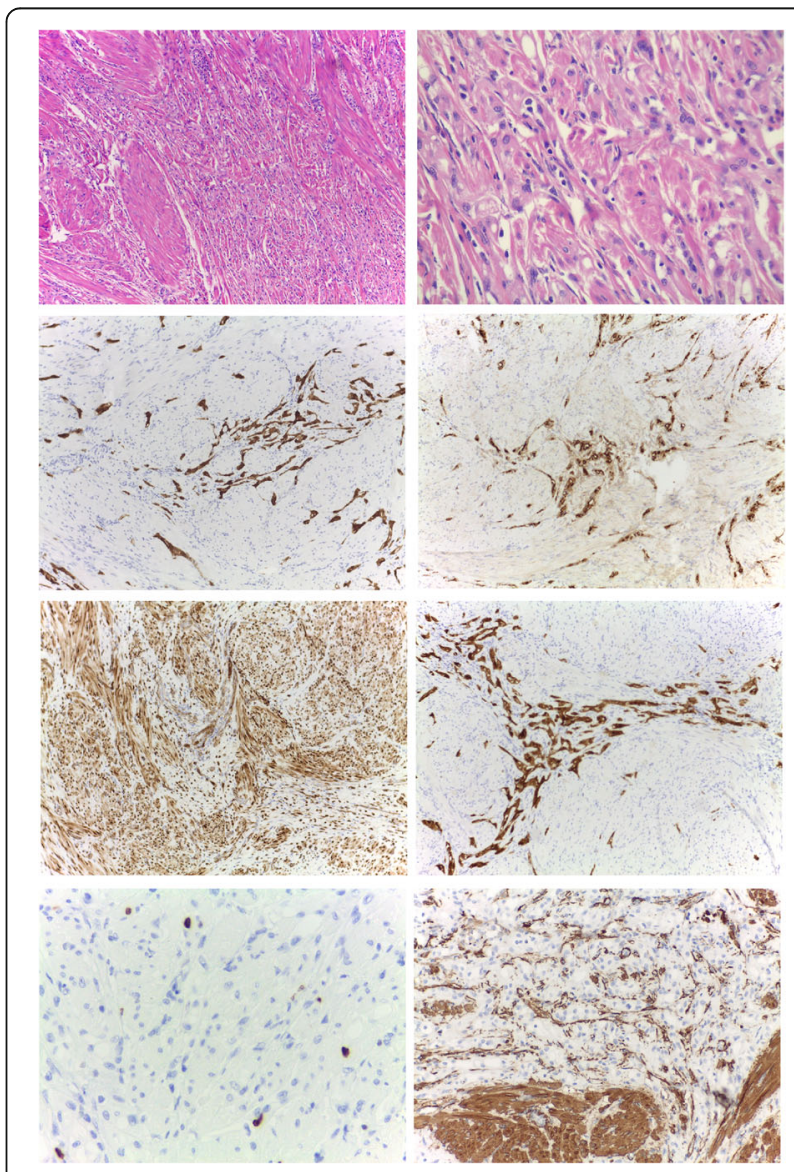

Fig. 2 Second case of leiomyoadenomatoid tumor. The HE staining showed an equivalent morphological pattern to the first case (10x and 40x). Immunohistochemical study revealed positivity for SMA (40x), Calretinin, D2-40, WT1, and cytokeratin (10x). The image shows a low proliferative $\mathrm{Kl}-67$ index (40x) 
leiomyoadenomatoid tumors - based on the histopathological and immunohistochemical findings (Figs. 1 and 2).

\section{Discussion and conclusion}

The term leiomyoadenomatoid tumor was first used by Epstein in 1992 as a morphological variant of AT with a prominent smooth muscle component (Epstein 1992). According to the World Health Organization (2014), AT of the uterus affect patients in a wide age range (45 years, in average). Most of the tumors are incidental findings and are located in the outer myometrium. They usually present as a solitary, small $(<4 \mathrm{~cm})$ and solid tumor, but sometimes can be diffuse, multifocal, large $(>10 \mathrm{~cm}$ ), or predominantly cystic (Kurman et al. 2014). Microscopically, AT are characterized by interanastomosing pseudovascular and pseudoglandular spaces, lined by flat or cuboidal cells, some with a signet ringlike appearance. A smooth-muscle hypertrophy component is often present. A lymphoid infiltrate can usually be seen (Kurman et al. 2014).

The majority of AT are readily diagnosed based on location and typical microscopic features. However, sometimes can be challenging, especially when facing cases of leiomyoadenomatoid tumor (Erra et al. 2009; Amérigo et al. 2010; Prangsgaard et al. 2013; Kopuz et al. 2015; Junainah et al. 2017). The microscopic appearance of this morphological variant may mimic a malignant tumor due to irregular pseudoinfiltration, with tubular formations that suggest presence of an infiltrating carcinoma or a malignant mesothelial neoplasm into a leiomyoma or into the myometrium (Epstein 1992; Bedir et al. 2014).

Table 1 Summary of immunohistochemical findings derived from leiomyoadenomatoid tumors, as reported in the literature

\begin{tabular}{|c|c|c|c|}
\hline Cases & Age & Site & Immunohistochemical findings \\
\hline $\begin{array}{l}\text { Current case } \\
\text { (first) }\end{array}$ & 38 & Uterine body & $\begin{array}{l}\text { CK7 (+), CK20 (-), calretinin (+), WT1 (+), D2-40 (+), CD31 (-), CD34(-), ERG (-), CDX-2 (-), } \\
\text { PAX8 (-), SMA (+) }\end{array}$ \\
\hline $\begin{array}{l}\text { Current case } \\
\text { (second) }\end{array}$ & 26 & Uterine body & AE1/AE3 $(+)$, calretinin $(+)$, WT1 $(+)$, D2-40 (+), KI67 (low proliferative index), SMA (+) \\
\hline $\begin{array}{l}\text { Amre R et al. } \\
\text { (2) }\end{array}$ & 52 & Uterine body & Pan-CK (+) \\
\hline $\begin{array}{l}\text { Mathew M } \\
\text { et al. (3) }\end{array}$ & 51 & Uterine body & Not performed \\
\hline $\begin{array}{l}\text { Bedir } \mathrm{R} \text { et al. } \\
\text { (4) }\end{array}$ & 51 & Uterine body & 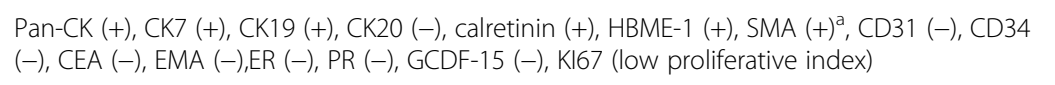 \\
\hline $\begin{array}{l}\text { Ersavaş S et al. } \\
\text { (5) }\end{array}$ & 30 & Uterine body & $\begin{array}{l}\text { CK7 (+), EMA }(+) \text {, HMBE-1 (+), calretinin (+), PR }(+) \text {, CK20 (-), Actin }(-) \text {, Caldesmon }(-) \text {, CD34 } \\
(-) \text {, CD31 (-), FVIIIRA }(-), \text { D2-40 }(-), \text { CEA }(-), \text { SMA }(+)^{\mathrm{a}}\end{array}$ \\
\hline $\begin{array}{l}\text { Sarma } N \text { et al. } \\
\text { (7) }\end{array}$ & 45 & Uterine body & Calretinin $(+)$, vimentin $(-)$, SMA $(+)^{\mathrm{a}}, \mathrm{K}$ K67 (low proliferative index) \\
\hline $\begin{array}{l}\text { Bahuguna } G \\
\text { et al. (8) }\end{array}$ & 65 & Uterine body (multicentric) & Calretinin (+), CEA (-), CD34 (-), KI67 (low proliferative index) \\
\hline $\begin{array}{l}\text { Dobrosz Z } \\
\text { et al. (9) }\end{array}$ & 57 & Uterine body & $\begin{array}{l}\text { CK7 }(+), \text { CK20 }(-), \text { HBME-1 }(+) \text {, calretinin }(+), \operatorname{CD} 31(-), \operatorname{CD} 34(-), \text { CEA }(-) \text {, actin }(+)^{a} \text {, SMA }(+)^{a} \text {, } \\
\text { vimentin }(+)^{a} \text {, desmin }(+)^{a} \text {, KI67 (low proliferative index) }\end{array}$ \\
\hline $\begin{array}{l}\text { Junainah EM } \\
\text { et al. (10) }\end{array}$ & 45 & $\begin{array}{l}\text { Uterine body and the fallopian } \\
\text { tubes (multicentric) }\end{array}$ & $\begin{array}{l}\text { AE1/AE3 (+), EMA (+), CAM } 5.2(+), \text { CK5/6 (+ focal), CD31 (-), CD34 }(-) \text {, SMA }(+)^{\mathrm{a}} \text {, caldesmon } \\
(+)^{\mathrm{a}} \text {, KI67 (low proliferative index) }\end{array}$ \\
\hline $\begin{array}{l}\text { Prangsgaard T } \\
\text { et al. (11) }\end{array}$ & 24 & Uterine body & $\begin{array}{l}\text { KL1 }(+) \text {, calretinin }(+) \text {, HBME-1 }(+), \text { CK7/8 }(+) \text {, vimentin }(+), \operatorname{CD} 31(-), \operatorname{CD} 34(-), \operatorname{SMA}(+)^{a} \text {, desmin } \\
(+)^{\mathrm{a}} \text {, KI67 (low proliferative index) }\end{array}$ \\
\hline $\begin{array}{l}\text { Amérigo J } \\
\text { et al. (12) }\end{array}$ & 55 & Uterine body & $\begin{array}{l}\text { AE1/AE3 (+), CK7 (+), CK20 (-),HBME-1 (+), calretinin (+), vimentin (+), CEA (-), FVIIIRA (-), } \\
\operatorname{CD} 31(-), \operatorname{CD} 34(-), \operatorname{CD} 117(-)\end{array}$ \\
\hline $\begin{array}{l}\text { Erra } S \text { et al. } \\
\text { (13) }\end{array}$ & 44 & Uterine serosa & $\begin{array}{l}\text { Pan-CK }(+), \text { CK5/6 }(+) \text {, calretinin }(+), \text { HBME-1 (+), vimentin }(+), \text { SMA }(+)^{\text {a }} \text {, CEA }(-) \text {, GCDF-15 (-), } \\
\text { E-cadherin }(-), \text { CD31 }(-) \text {, CD34 }(-),\end{array}$ \\
\hline $\begin{array}{l}\text { Kopuz A et al. } \\
\text { (14) }\end{array}$ & 32 & Uterine body & Pan-CK (+), calretinin (+), D2-40 (+), CD31 (-), CEA (-), KI67 (low proliferative index) \\
\hline $\begin{array}{l}\text { Hong R et al. } \\
(15)\end{array}$ & 24 & $\begin{array}{l}\text { Uterine body and ovary } \\
\text { (multicentric) }\end{array}$ & CK7 $(+)$, CK20 $(-)$, calretinin $(+)$, desmin $(+)^{\mathrm{a}}$, SMA $(+)^{\mathrm{a}}$, CEA $(-)$, vimentin $(-)$ \\
\hline $\begin{array}{l}\text { Ranjan R et al. } \\
(14)^{b}\end{array}$ & $\begin{array}{l}32- \\
43\end{array}$ & Uterine body & $\mathrm{CK}(+), \mathrm{WT} 1(+), \mathrm{ER}(-), \mathrm{SMA}(+)^{\mathrm{a}}, \mathrm{CD} 34(+)^{\mathrm{a}}$, calretinin $(+)$ \\
\hline
\end{tabular}

Abbreviations: CD Cluster of differentiation, CEA Carcinoembryonic antigen, CK Cytokeratin, EMA Epithelial membrane antigen, ER Estrogen receptor, ERG Transcriptional regulator ERG related gene, FVIIIRA Factor VIII-related antigen, GCDF-15 gross cystic disease fluid protein-15, HBME-1 Hector Battifora mesothelial-1, PAX8 paired box gene 8, PR Progesterone receptor, SMA Smooth muscle actin, WT1 Wilms' tumor 1

${ }^{\mathrm{a}}$ In smooth muscle component

${ }^{\mathrm{b}}$ Three cases 
Some authors argue that leiomyoadenomatoid tumors should be considered a specific subtype of AT. Amérigo et al. and Prangsgaard et al. support such argument based on the presence of the AC intermixed with the smooth-muscle proliferation and on the fact that their cases had a well-demarcated lesion in AT as opposed to the previously reported cases of leiomyoadenomatoid tumors (Hong et al. 2009; Prangsgaard et al. 2013).

In both cases of the present report, the microscopic examination of the masses showed a very prominent hypertrophic smooth muscle bundles, simulating a leiomyoma with an AC infiltrating appearance, causing diagnosis difficulty because of resembling a malignant neoplasm. The same challenge has been faced by others and, just like in our own cases, immunohistochemical analysis was needed for correct diagnosis (Epstein 1992; Amre et al. 2005; Erra et al. 2009; Hong et al. 2009; Amérigo et al. 2010; Dobrosz et al. 2013; Prangsgaard et al. 2013; Bedir et al. 2014; Sarma et al. 2014; Bahuguna et al. 2014; Ersavaş et al. 2015; Kopuz et al. 2015; Ranjan et al. 2015; Junainah et al. 2017).

Immunohistochemically, AT show positivity for AE1AE3, CAM 5.2, CK7, CK18 and 19, calretinin, WT-1, D2-40, and HMBE-1 (Kurman et al. 2014). As found in the literature review, already described cases present gland like areas lined by cuboidal epithelioid cells staining positive for WT1, D2-40 and calretinin, just like the cases discussed in this report (Epstein 1992; Erra et al. 2009; Hong et al. 2009; Amérigo et al. 2010; Dobrosz et al. 2013; Prangsgaard et al. 2013; Bedir et al. 2014; Sarma et al. 2014; Bahuguna et al. 2014; Ersavaş et al. 2015; Kopuz et al. 2015; Ranjan et al. 2015; Junainah et al. 2017). A summary of location and immunohistochemical findings of previously reported cases is presented in Table 1.

A total of 16 AT cases with leiomyoadenomatoid morphological presentation were found in the performed literature review, none reported in Brazil. In 7 cases, the immunohistochemical panel included CK7 and CK20, being all positive for CK7 and negative for CK20. Ten cases stained positive for calretinin. Of 3 cases, 1 stained negative for D2-40. Vascular immunomarkers were performed in 10 cases, all resulting negative. Finally, the proliferative index was low among 7 cases tested (Epstein 1992; Amre et al. 2005; Erra et al. 2009; Hong et al. 2009; Amérigo et al. 2010; Dobrosz et al. 2013; Prangsgaard et al. 2013; Bedir et al. 2014; Sarma et al. 2014; Bahuguna et al. 2014; Ersavaş et al. 2015; Kopuz et al. 2015; Ranjan et al. 2015; Junainah et al. 2017).

In difficult cases needing differential diagnosis of metastatic adenocarcinoma, the immunohistochemical panel may include CEA, FVIIIRA, HBME-1, MOC31, BER-EP4, B72.3, and CD15 (Junainah et al. 2017). The muscular component is positive for smooth muscle markers, like SMA and caldesmon, while negative in AC (Prangsgaard et al. 2013; Bahuguna et al. 2014; Ersavaş et al. 2015; Junainah et al. 2017). These tumors can also be mistaken for leiomyomas with degenerative changes, epithelioid hemangioendotheliomas, and metastatic adenocarcinomas. Immunohistochemical studies may help in differentiating these lesions and reaching a precise diagnosis (Bahuguna et al. 2014).

We concluded that the leiomyoadenomatoid tumor is an unusual morphological presentation of AT and may mimic primary or metastatic malignant neoplasm due to its infiltrative pattern. Therefore, pathologists should be aware of these tumors for differential diagnosis, interpreting morphological findings together with mesenchymaloriginated immunohistochemical markers' results to avoid misdiagnosing.

\section{Abbreviations \\ AC: Adenomatoid component; AT: Adenomatoid tumor; CD: Cluster of differentiation; CEA: Carcinoembryonic antigen; CK: Cytokeratin; ERG: Transcriptional regulator ERG; FVIIIRA: Factor VIII-related antigen; HBME- 1: Hector Battifora mesothelial-1; ER: Estrogen receptor; PAX8: Paired box gene 8; PR: Progesterone receptor; SMA: Smooth muscle actin; WT1: Wilms' tumor 1}

\section{Acknowledgments}

The authors would like to thank the CEDAP technical team for indispensable support.

\section{Authors' contributions}

FA Adorno contributed to the study conception and design, acquisition and analysis of data and drafting of the manuscript. J Stall contributed to the manuscript writing. KMPA Coelho, GS Bublitz and PHC França critically reviewed the manuscript for intellectual content and final approval.

\section{Funding}

No funding was received for this study.

\section{Availability of data and materials}

The datasets used and/or analyzed during the current study are available from the corresponding author on reasonable request.

\section{Ethics approval and consent to participate}

The study protocol was approved by the Research Ethics Committee of Dona Helena Hospital (Approval No.: 3.733.627).

\section{Consent for publication}

Not applicable.

\section{Competing interests}

The authors have no conflicts of interest to declare.

\section{Author details}

${ }^{1}$ Pathology Residency Program, São José Municipal Hospital, Joinville, Santa Catarina, Brazil. ${ }^{2}$ Centro de Diagnósticos Anátomo-Patológicos (CEDAP), Joinville, Santa Catarina, Brazil. ${ }^{3}$ Post-graduate Program in Health and Environment, Universidade da Região de Joinville (UNIVILLE), Joinville, Santa Catarina, Brazil.

Received: 24 October 2020 Accepted: 21 December 2020

Published online: 04 February 2021

\section{References}

Amérigo J, Amérigo-Góngora M, Giménez-Pizarro A, Velasco FJ, Gallardo SP, González-Cámpora R (2010) Leiomyo-adenomatoid tumor of the uterus: a distinct morphological entity? Arch Gynecol Obstet 282:451-454 
Amre R, Constantino J, Lu S, Charney D (2005) Pathologic quiz case: a 52-year-old woman with a uterine mass. Leiomyo-adenomatoid tumor of the uterus. Arch Pathol Lab Med 129:e77-e78

Bahuguna G, Misra D, Malhotra V, Sinha A (2014) Multicentric leiomyoadenomatoid tumor of the uterus: a rare and distinct morphological entity. J Obstet Gynaecol India 64:152-153

Bedir R, Üstüner I, Mürtezaoglu AR, Bagci P, Güçer H (2014) Leiomyoadenomatoid tumor of the uterus: case report and literature review. Natl Lab Med 3:15-18

Dobrosz Z, Paleń P, Właszczuk P, Stojko R (2013) An atypical leiomyoadenomatoid tumor of the uterus - a case report and literature review. Ginekol Pol 84:730-732

Epstein JI (1992) Differential diagnosis in pathology: urologic disorders. IgaskuShoin, New York, pp 173-174

Erra S, Pastormerlo M, Gregori G, Costamagna D, Pavesi M (2009) A case of leiomyoadenomatoid tumour of uterine serosa: speculations about differential diagnosis. BMJ Case Rep 2009:bcr02.2009.1586

Ersavaş S, Eliyatkın N, Sayhan S, Zihni I, Sarıgül Ç, Yağcı A (2015) Leiomyoadenomatoid tumor of the uterus in pregnancy: a case report. Tepecik Eğit Hast Derg 25:120-124

Hong R, Choi D-Y, Choi SJ, Lim S-C (2009) Multicentric infarcted leiomyoadenomatoid tumor: a case report. Int J Clin Exp Pathol 2:99-103

Junainah EM, Elrashidy A, Elnashar H, Huwait HF, Albezrah NKA, Bakr AS et al (2017) Multifocal leiomyo-adenomatoid tumour of the uterus a distinct pathological entity. J Histol Cell Biol 1:13-15

Kopuz A, Karadeniz T, Kopuz AY, Özcan A, Turan V, Özeren M (2015) Leiomyoadenomatoid tumor of the uterus: case report. Turkiye Klinikleri Gynecol Obst-Spec Top 25:125-128

Kurman RJ, Carcangiu ML, Herrington CS, Young RH (2014) WHO classification of tumours of female reproductive organs. IARC, Lyon

Mathew M, Goel G (2010) Leiomyoadenomatoid tumor of the uterus. Turk Patoloji Derg 26:168-169

Prangsgaard T, Lykke R, Hansen ES (2013) Leiomyo-adenomatoid tumor of the uterus: report of a rare entity. J Gynecol Surg 29:219-221

Ranjan R, Singh L, Nath D, Sable MN, Malhotra N, Bhatla N et al (2015) Uterine adenomatoid tumors: a study of five cases including three cases of the rare leiomyoadenomatoid variant. J Obstet Gynaecol India 65:255-258

Sarma NH, Srinivasulu M, Suchitra MJ (2014) Leiomyoadenomatoid tumor of the uterus: report of a rare entity and review of the literature. Indian J Pathol Microbiol 57:450-452

\section{Publisher's Note}

Springer Nature remains neutral with regard to jurisdictional claims in published maps and institutional affiliations.

Ready to submit your research? Choose BMC and benefit from:

- fast, convenient online submission

- thorough peer review by experienced researchers in your field

- rapid publication on acceptance

- support for research data, including large and complex data types

- gold Open Access which fosters wider collaboration and increased citations

- maximum visibility for your research: over $100 \mathrm{M}$ website views per year

At BMC, research is always in progress.

Learn more biomedcentral.com/submissions 